\section{Miniature Head Lettuce Yield and Anthocyanin Concentration under High Tunnels and the Field in Georgia}

\author{
Suzanne O’Connell ${ }^{1}$
}

ADDITIONAL INDEX WORDs. hoop house, Lactuca sativa, organic, plasticulture, specialty crop

Summary. This study evaluated the yield of eight miniature lettuce (Lactuca sativa) cultivars (i.e., mini-lettuce) grown under organically managed high tunnels compared with a field system during two spring seasons in Georgia. Mini-lettuce required an average of 36 to 40 days to harvest in both systems with a $86 \%$ to $97 \%$ marketability rate. The high tunnels provided a heat gain on the coldest days, decreased leaf wetness, and resulted in a lower daily light integral compared with the field. In 2015, mini-lettuce yields were similar between the high tunnel and field, but in 2016, yields were greater under the high tunnels. In 2016 only, there was a significant system by cultivar interaction for yield, suggesting that the high tunnels provided a yield increase for 'Baby Green Oakleaf' and 'Spretnak' mini-lettuce. Differences in the daily light integral between the high tunnels and field appeared to affect the accumulation of anthocyanins in red-pigmented mini-lettuce. Anthocyanin concentrations were $26 \%$ to $194 \%$ greater in mini-lettuce grown in the field compared with under high tunnels. The cultivar Rhazes had the greatest anthocyanin concentrations of all red-pigmented mini-lettuce evaluated but also lower yields.

$\mathrm{E}$ fforts to identify promising high-value crops that grow well under high tunnels (i.e., unheated, passively ventilated, greenhouse-like structures) are ongoing in the southeast region of the United States. Some of the identified benefits of growing under high tunnels include increased crop protection from adverse weather events, opportunities for season extension, potential to maximize produce quantity and quality, and quicker crop growth (Borrelli et al., 2013; Jayalath et al., 2017; O'Connell et al., 2012; Rho et al., 2020; Rogers and Wszelaki, 2012). Since 2010, competitive cost-share

Received for publication 28 Sept. 2020. Accepted for publication 9 Nov. 2020.

Published online 5 January 2021

${ }^{1}$ Department of Horticulture, University of Georgia, 1111 Miller Plant Sciences, Athens, GA 30602

We are grateful for funding provided by a private foundation that wishes to remain anonymous and the

University of Georgia. This work was made possible with the help of Robert Tate, Theekshana Jayalath, Ryan McNeill, Carl Hall, Carl Ruiz, Jose Reyes de Corcuera, Jason Lessl, Alexander Greer, and Esther van Knapp. We also acknowledge the reviewers for their constructive suggestions to improve the manuscript.

S.O. is the corresponding author. E-mail: Suzanne. oconnell@gmail.com.

This is an open access article distributed under the CC BY-NC-ND license (https://creativecommons.org/ licenses/by-nc-nd/4.0/).

https://doi.org/10.21273/HORTTECH04744-20 programs to build high tunnels, administered by the Natural Resource Conservation Service (NRCS), have provided an additional incentive for farmers, especially organic farmers, to invest and explore the benefits of growing under high tunnels. Although the total number of farms that use high tunnels in Georgia is undocumented, more than 600 structures received NRCS cost-share awards since 2015 (J. Dangler, personal communication). A recent survey conducted in Georgia and Florida identified salad greens, pepper ( $\mathrm{Cap}$ sicum annuum), cooking greens, tomato (Solanum lycopersicum), and cucumber (Cucumis sativus) as the most popular organic high tunnel crops to grow (Zhao et al., 2017).

Lettuce (Lactuca sativa) is the most popular type of salad green and considered the most valuable vegetable crop in the United States [U.S. Department of Agriculture (USDA), 2017a]. The organic lettuce market is currently worth $\$ 277$ million (USDA, 2017b). Presently, Georgia is a relatively small producer of lettuce at 48 total acres for the fresh market, and there is not much research available on the cultivation of conventional or organic lettuce in this region (USDA, 2019). There are $\approx 80$ farms in Georgia, ranging in size from 1 to 2000 acres, with a USDA certified organic component; these farms report more than $\$ 29$ million in total organic product sales (USDA, 2020).

Exploring the production of organic, specialty lettuce under high tunnels and the field may help producers in the southeast U.S. region expand their offerings to meet growing demand. The market share of specialty lettuce has been growing rapidly since the 1980s and includes precut, baby leaf and mini-lettuce. Mini-lettuce is perceived to have increased health benefits, a time-saving convenience, and be less wasteful for small households (Kuepper et al., 2002; Schaffner, 2002; Waycott and Ryder, 1994). Mini-lettuce is primarily harvested and sold as small, intact heads. Because mini-lettuce is not damaged by multiple cuts, it generally retains the visual quality and phytochemical content longer than other types of specialty lettuce (Saltveit, 2003). Multiple mini-lettuce heads,

\begin{tabular}{llll}
\hline $\begin{array}{l}\text { Units } \\
\text { To convert U.S. to SI, } \\
\text { multiply by }\end{array}$ & U.S. unit & Sl unit & $\begin{array}{l}\text { To convert SI to U.S., } \\
\text { multiply by }\end{array}$ \\
\hline 1 & $\%$ & $\mathrm{~g} / \mathrm{l} 00 \mathrm{~g}$ & $\mathrm{l}$ \\
0.4047 & $\mathrm{acre}(\mathrm{s})$ & $\mathrm{ha}$ & 2.4711 \\
0.2366 & $\mathrm{cup}(\mathrm{s})$ & $\mathrm{L}$ & 4.2268 \\
29,574 & $\mathrm{fl} \mathrm{oz}$ & $\mu \mathrm{L}$ & $3.3814 \times 10^{-5}$ \\
29.5735 & $\mathrm{fl} \mathrm{oz}$ & $\mathrm{mL}$ & 0.0338 \\
0.3048 & $\mathrm{ft}$ & $\mathrm{m}$ & 3.2808 \\
3.7854 & $\mathrm{gal}$ & $\mathrm{L}$ & 0.2642 \\
2.54 & inch(es) & $\mathrm{cm}$ & 0.3937 \\
1.1209 & $\mathrm{lb} / \mathrm{acre}$ & $\mathrm{kg} \cdot \mathrm{ha}^{-1}$ & 0.8922 \\
0.0254 & $\mathrm{mil}(\mathrm{s})$ & $\mathrm{mm}$ & 39.3701 \\
1.6093 & $\mathrm{mph}$ & $\mathrm{km} \cdot \mathrm{h}^{-1}$ & 0.6214 \\
28.3495 & $\mathrm{oz}$ & $\mathrm{g}$ & 0.0353 \\
28,350 & $\mathrm{oz}$ & $\mathrm{mg}$ & $3.5274 \times 10^{-5}$ \\
14.7868 & $\mathrm{tablespoon}(\mathrm{s})$ & $\mathrm{mL}$ & 0.0676 \\
$\left({ }^{\circ} \mathrm{F}-32\right) \div 1.8$ & ${ }^{\circ} \mathrm{F}$ & ${ }^{\circ} \mathrm{C}$ & $\left({ }^{\circ} \mathrm{C} \times 1.8\right)+32$ \\
& & &
\end{tabular}

Hortlechnology $\cdot$ February $202131(1)$ 
with different colors and shapes, are often packaged together or sold as mix-and-match in bags or clamshell containers. Supermarket offerings include variety packs comprising three to four mini-lettuce heads under brand names such as "Private Selection Artisan Lettuce" and "Tanimura Artisan Lettuce," currently retailing for about $\$ 3$ to $\$ 4$ per container. Standards for miniature produce do not currently exist in the United States, and therefore desired attributes are decided by market preferences (Maynard, 2006).

Studies focused on mini-lettuce are limited. A 1-year study in Brazil evaluated three mini-lettuce cultivars, Renoir, Sartre, and Tudela, at two plant spacings under high tunnels (Takahashi and Cardoso, 2014). Although the mini-lettuce yield was greater at a $16-\mathrm{cm}$ plant spacing $\mathrm{com}-$ pared with $20-\mathrm{cm}$ plant spacing, the $20-\mathrm{cm}$ plant spacing resulted in greater marketable yields and less disease incidence during a warm and humid growing season (Takahashi and Cardoso, 2014). Another study evaluated three new crisphead minilettuce cultivars for field production in California, New York, and Pennsylvania (Waycott and Ryder, 1994). Their results suggested that the new crisphead mini-lettuce cultivars were more heat tolerant and bolt resistant than full-size lettuce (Waycott and Ryder, 1994).

Research focused on full-sized lettuce heads under high tunnels may have some applicability to minilettuce production. A multiyear comparison of winter/early spring lettuce production under high tunnels and the field was carried out in Texas, Tennessee, and Washington (Wallace et al., 2012). The high tunnels helped moderate temperature swings at two of the three locations, and total lettuce yields were similar or greater between high tunnel and field depending on the site (Wallace et al., 2012). A Kansas study found that leaf lettuce grown under high tunnels in the summer led to increased bolting and lower yields compared with the field (Zhao and Carey, 2009). Their results suggested that efforts to decrease heat and light stress on the high tunnel lettuce crop (e.g., shadecloth, mist system, etc.) were required for greater success in their area (Zhao and Carey, 2009).
Lastly, an experiment in Georgia concluded that the production of romaine and butterhead lettuce had the same or greater yields when grown under high tunnels compared with the field (Jayalath et al., 2017). In addition, the high tunnel lettuce required fewer days to harvest compared with the field, and there were no differences in pest or disease incidence (Jayalath et al., 2017).

Green is the most common lettuce leaf color in the United States, but red/purple is also popular. Consumers use color as an indicator of vegetable freshness, ripeness, and/or nutrient content (Schifferstein et al., 2019). Nutritional experts advocate "eating a rainbow of healthy foodbased colors" including $21 / 2$ to 3 cups of vegetables daily (Minich, 2019; U.S. Department of Health and Human Services and USDA, 2015). Although all lettuce has nutritional benefits, red lettuce may have additional health benefits. Redpigmented lettuces are one of only seven vegetables commonly eaten in the United States, that contains anthocyanin (Wu et al., 2006). Although there are currently no dietary guidelines for anthocyanin, it is widely recognized that health benefits include antioxidant capabilities, cancer cell and inflammation inhibition, vasoprotection, and improved visual health (Khoo et al., 2017; McGhies and Walton, 2007; Wallace and Guisti, 2015). The majority of anthocyanins in the U.S. diet are provided by fruit, berries, grape (Vitis vinifera) juice, or wine, but red leaf lettuce was estimated to contribute up to $12 \%(\approx 1.5 \mathrm{mg})$ of the total anthocyanin intake per day $(\approx 12.7$ $\mathrm{mg}$ ) (Wu et al., 2006).

Production of anthocyanin is an adaptive ability that some plants possess to protect themselves from oxidative stress and deoxyribonucleic acid damage from high levels of red, blue, and/or ultraviolet wavelengths (Krizek, 2004; Stafford, 1994; Steyn et al., 2002). High tunnels may affect the accumulation of anthocyanins by impacting both the total light quantity and quality reaching the crop canopy. Growers use a wide variety of polyethylene films to construct high tunnel roofs and walls, making it difficult to predict specific impacts on the light environment. Growers in the United States that receive a NRCS cost-share award are required to use polyethylene film that is at least 6 mils, ultraviolet-resistant, and has a minimum 4-year lifespan (USDA, 2015). Polyethylene films used by U.S. growers are not always comparable to those used by high tunnel growers in other countries.

A series of studies were conducted, primarily in Europe, to examine the effect of high tunnel polyethylene film on the anthocyanin content in red leaf lettuce. GarciaMacias et al. (2007) found that the red-pigmented 'Lollo Rosso' lettuce grown under a polyethylene film that blocked $22 \%$ to $40 \%$ of ultraviolet light had lower yields and greater anthocyanin concentrations compared with lettuce grown under a film that blocked $94 \%$ to $99 \%$ of ultraviolet light. Two additional studies found that the anthocyanin content of 'Lollo Rosso' lettuce was greater for polyethylene films with greater ultraviolet-transmittance (Ordidge et al., 2010; Tsormpatsidis et al., 2008).

Considering the existing body of knowledge, the goals of this study were to evaluate the effect of high tunnels and cultivar type on spring organic mini-lettuce production in Georgia by 1) comparing mini-lettuce yields grown under high tunnels and the field, and 2) comparing anthocyanin concentration of multiple red-pigmented mini-lettuce cultivars grown under high tunnels and the field.

\section{Materials and methods}

Site BACKGround. The study was conducted at the Durham Horticulture Research Farm located in Watkinsville, GA (lat. $33.88689^{\circ} \mathrm{N}$, long. $83.41941^{\circ} \mathrm{W}$ ) during Spring 2015 and 2016. This area of Georgia is considered a humid, subtropical climate in plant hardiness zone $8 \mathrm{a}$ (USDA, 2012). Soils at this site are categorized as a well-drained Cecil sandy loam soil that has been eroded overtime so that the plow layer now extends into the red sandy clay loam subsoil [CYB2 (USDA, 1968)]. The project site has been certified organic since 2012 , and all agricultural production methods were performed under the guidelines of the USDA National Organic Program certification standards (U.S. Government Publishing Office, 1990). There was 
no recent history of aster family (Asteraceae) crops in the project area before our 2-year study.

High tunnels. Two gothicshaped high tunnels (96 ft long $\times$ $30 \mathrm{ft}$ wide $\times 12 \mathrm{ft}$ tall) built in 2014 were used for the experiment (Snow Arch Series; Atlas Greenhouses, Alapaha, GA). The high tunnels were oriented east-west to minimize high tunnel surface area exposed to the prevailing westerly winter winds. High tunnel features included bows every $6 \mathrm{ft}$ and automated 6 -ft-tall fabric drop-down curtains (12 mil thick). There was an inflated double-polyethylene film roof (each layer was 6 mil thick) on both high tunnels. The film property qualities were described as $90 \%$ light transmission, 25\% light diffusion, and 95\% ultraviolet-blocking (SunView 4; POLYAG. Corp., San Diego, CA).

The high tunnel end walls were composed of twin-wall polycarbonate. Each end wall had two, 8-ft-wide sliding doors allowing for a 16-ft-wide opening when fully opened. According to the high tunnel manufacturer, these structures had an estimated wind load capacity of $90 \mathrm{mph}$ with a 3-s wind gust. Automatic drop-down side curtains were set to close at $10 \pm 0.5{ }^{\circ} \mathrm{C}$ and remained open when temperatures were $\geq 11^{\circ} \mathrm{C}$. Side curtains were closed when heavy rain or winds (>15 mph) were predicted to protect plants from wind damage and to minimize water intrusion (i.e., roof runoff or rain blowing in through the sides). During warm periods (i.e., $\geq 11{ }^{\circ} \mathrm{C}$ ) end walls were kept open as much as possible.

Experimental Design. The experiment was a split-plot design, and treatments were replicated four times [two blocks in each commercial-sized high tunnel and four blocks total in the field (Fig. 1)]. The main plot was production system (i.e., high tunnel or field) and the subplot treatment was cultivar. Crop management and data collection were carried out by block. Blocks were randomized each year and guard rows comprising fullsized romaine lettuce heads were planted on lateral sides of each high tunnel to minimize edge effects from sun, wind, and so on. Each block was a 28-inch-wide by 6 -ft-long raised bed with 6 -inch in-row and 12 -inch between-row spacing resulting in a total of 10 mini-lettuce plants per experimental unit.
Mini-lettuce cultivars were selected based on descriptions about their dwarf size, availability of organic or untreated seed, comparable estimated days to harvest ( $\approx 40$ to $50 \mathrm{~d}$ ), and leaf color. Eight mini-lettuce cultivars were evaluated: Australe, Baby Green Oakleaf, Bambi, Breen, Dragoon, Rhazes, Spretnak (Johnny's Selected Seeds, Winslow, $\mathrm{ME}$ ), and Maraine (Osborne Seed Co., Mount Vernon, WA). Breen and Dragoon were romaine-type lettuce, and the other six cultivars were butterhead-type lettuce. 'Australe', 'Breen', 'Maraine', and 'Rhazes' were all described by seed catalogs to have varying degrees of red pigmentation; all other cultivars had entirely green leaf tissue. All cultivars, except Baby Green Oakleaf, were reported to be resistant to downy mildew (Bremia lactucae). In addition, 'Australe', 'Dragoon', and 'Spretnak' were reported to have intermediate resistance to lettuce mosaic virus (Potyvirus sp.).

Lettuces were seeded on 6 Mar. 2015 and 4 Mar. 2016 then transplanted to the high tunnels or field $\approx 5$ weeks later, 10 Apr. 2015 and 7 Apr. 2016. Harvesting occurred on two dates each year, 12 and 19 May 2015 and 13 and 20 May 2016. Transplants were grown on-site in a heated certified organic greenhouse maintained at $13 / 21{ }^{\circ} \mathrm{C}$ (night/day) temperatures.

Seeds were sown into 2.25-inchdeep six-packs (\#L-1206; Land Mark Plastics, Akon, $\mathrm{OH}$ ) filled with organic potting media (Sunshine Natural \& Organic Professional Growing Mix \# 1; Sun Gro Horticulture, Agawam, MA). Overhead irrigation was administered by hand as needed to seedlings. A $4 \mathrm{~N}-1.3 \mathrm{P}-2.5 \mathrm{~K}$ soluble fish and seaweed fertilizer (AgGrand Organic Series; Amsoil, Superior, WI) was applied once per week at a rate of 2 tablespoons/gal of water during the third and fourth week after seeding. Seedlings were acclimated to the outside environment $\approx 1$ week before transplanting to either the high tunnels or in the field. Fertilizer applications to the high tunnels or field were based on soil sample results taken 2 months before the planting dates. Fertilizers were broadcasted over each block and incorporated $\approx 1$ inch into the soil surface using hand rakes. Preplant fertilizers used included feather meal, potassium sulfate, and boron applied 1 week before planting (Table 1). In 2016, soil tests recommended adding potassium and lime to the field system and magnesium to the high tunnel system. Therefore, different fertilizer products and rates were applied to the high tunnels and the field to provide optimal levels of nutrients for the lettuce crop each year.

Each high tunnel and field replication included sensors to measure air temperature and relative humidity [RH (VP-3; Decagon Devices, Pullman, WA)], photosynthetic photon flux [ PPF (QSO-S PAR Photon Flux; Apogee Instruments, Logan, UT)], and leaf wetness [LW (Decagon Devices)]. The air temperature and $\mathrm{RH}$ probes were placed inside radiation shields provided by the manufacturer. Average values for each parameter were recorded at hourly intervals. Using these hourly values, daily average, daily maximum, and daily minimum levels were calculated. Each 24-h period began and ended at 7:00 AM. Light sensors, air temperature sensors, and LW sensors were placed 21 , 18 , and 12 inches above the soil surface, respectively. Leaf wetness sensors were mounted at a $45^{\circ}$ angle. PPF sensors were leveled and oriented with their cables pointing to magnetic north. The daily light integral (DLI) was calculated from the PPF. The DLI represents the number of photosynthetically active photons in the 400to $700-\mathrm{nm}$ range that are delivered to a specific area over a 24-h period. Light and LW sensors were wiped with a clean, soft cloth at frequent intervals according to manufacture recommendations to maintain the measurement accuracy throughout the growing season.

Pest and disease management. Integrated pest management scouting was carried out twice each week. In 2015, fire ants (Solenopsis sp.), aphids (Aphidoidea sp.), and armyworms (Spodoptera exigua) were the major insect pests, along with lettuce drop disease (Sclerotinia sclerotiorum) in both systems. Two spinosad-based products were used to manage fire ants including Entrust naturalyte insect control (Dow Agro Sciences, Indianapolis, IN) and Come and Get It fire ant killer bait [Ferti-lome, Bonham, TX (this product no longer carries an Organic Materials Review 
Institute certification)]. Bacillus thuringiensis (DiPel DF; Valent USA Corp., Walnut Creek, CA) was used one time in both the high tunnels and field to manage armyworms. All products were administered at the recommended label rates.

In 2016, a biological fungicide containing Coniothyrium minitans (Contans WG; Sipcam Agro USA, Durham, NC) was also applied to the surface of raised beds in both systems, at a rate of $2 \mathrm{lb} /$ acre as a soil drench at transplanting time to reduce the incidence of lettuce drop disease. In addition, plants infected with lettuce drop were removed along with the surrounding surface soil along with visible sclerotia and disposed. Dead or severely damaged plants were recorded and replaced up to 2 weeks from their original transplanting date. After 2 weeks, plants that died were not replaced and thus resulted in fewer plants per plot.

Irrigation was generally administered every other day, although the interval varied depending on the weather, soil moisture, and plant growth stage. There was one drip tape per row of lettuce (i.e., two drip tapes per bed) with emitters every 8 inches and a flow rate of $0.34 \mathrm{gal} / \mathrm{h}$ (Toro Microirrigation, El Cajon, CA). In 2015 , each irrigation cycle was 60 to $120 \mathrm{~min}$ long. In 2016, the irrigation cycles were reduced to $60 \mathrm{~min}$ long to minimize the amount of time the soil surface was moist to help manage lettuce drop disease.

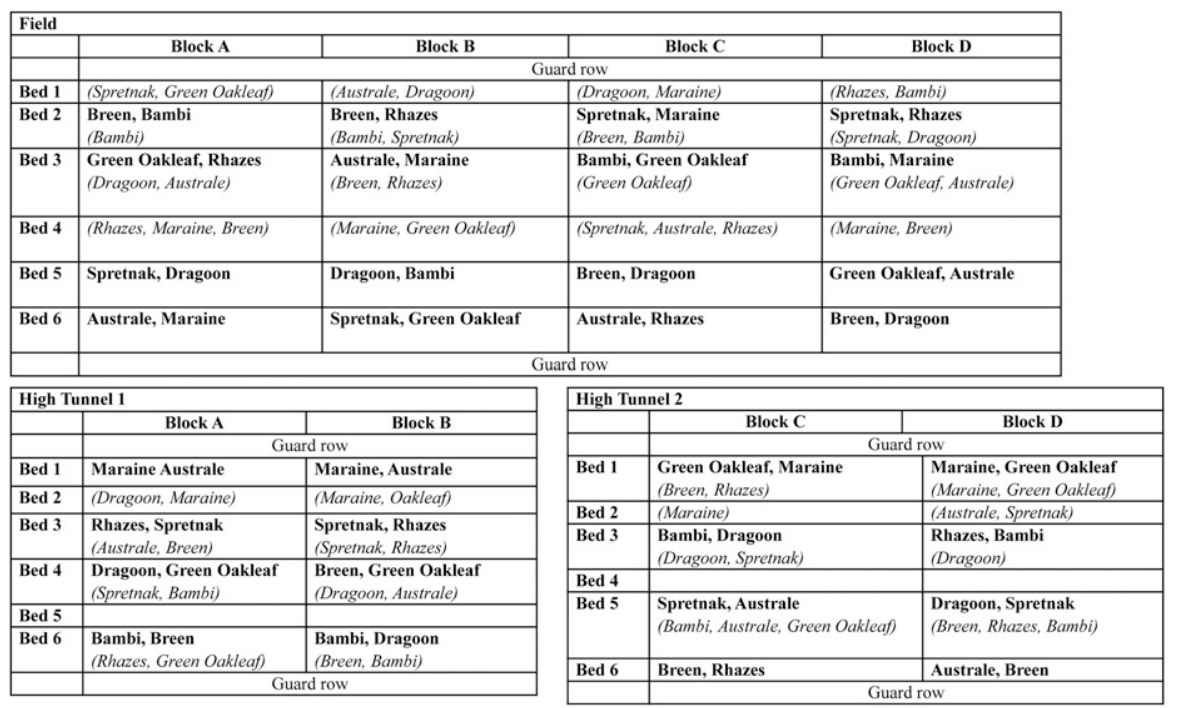

Fig. 1. Experimental plot plans for mini-lettuce variety trial under high tunnels and the field in Watkinsville, GA. Both high tunnels and the field were oriented east-west. Each block was a 28 -inch-wide by 6 -ft-long raised bed with 6 -inch inrow and 12 -inch between-row spacing resulting in a total of 10 mini-lettuce plants per experimental unit. Blocks were randomized each year. Boldface represents treatments in 2015 and italicized font within parenthesis represents treatments in 2016; 1 inch $=2.54 \mathrm{~cm}, 1 \mathrm{ft}=0.3048 \mathrm{~m}$.
Harvesting protocols. All plots were assessed two times per week for harvesting. Lettuce was harvested when more than $75 \%$ of the plants per block were considered marketable. Judgments about marketable size were made from comparisons to mini-lettuce for sale at regional grocery stores and farmers markets. Lettuce heads were not washed before recording the number and weight of marketable and nonmarketable heads from each plot. Nonmarketable heads were categorized as undersized, bolted, or damaged by insects.

In 2015, visual assessments of lettuce with red-pigmented leaf tissue were carried out after heads were rinsed with water. Two evaluators compared the external leaf tissue of two marketable lettuce heads chosen at random from each treatment for estimated percentage with red pigmentation. In 2016, in an effort to further quantify leaf color differences, the five outermost leaves from two marketable lettuce heads, chosen at random from each treatment, were removed to comprise a pooled sample of 10 leaves for anthocyanin analysis. Only the outermost leaves were sampled because anthocyanin accumulation is generally concentrated in the plant tissues exposed to the most direct light (Krizek, 2004). The leaf samples were stored for up to 1 week at $1{ }^{\circ} \mathrm{C}$ and $90 \% \mathrm{RH}$. Lettuce leaves were then freeze-dried using thermocouples to monitor the leaf tissue temperature (VirTis Unitop 600L Freezemobile; SP Scientific Products, Gardiner, NY). Freeze-dried samples were stored at $-80{ }^{\circ} \mathrm{C}$ until anthocyanin analysis occurred.

Total anthocyanin concentrations were determined with the $\mathrm{pH}$ differential spectrophotometric

Table 1. Preplant fertilizer inputs for mini-lettuce cultivar trial under organically managed high tunnels or field, across two spring seasons in Watkinsville, GA.

\begin{tabular}{llllr}
\hline Yr & \multicolumn{1}{c}{ Input } & \multicolumn{1}{c}{ Analysis } & \multicolumn{1}{c}{ Source } & Application rate (lb/acre) $^{\mathbf{z}}$ \\
\hline 2015 & Feather meal & $13 \mathrm{~N}-0 \mathrm{P}-0 \mathrm{~K}$ & Mason City By-products, Mason City, IA & 769 \\
& Potassium sulfate (field only) & $0 \mathrm{~N}-0 \mathrm{P}-41.5 \mathrm{~K}$ & SQM North America, Atlanta, GA & 192 \\
& Potassium sulfate (high tunnel only) & $0 \mathrm{~N}-0 \mathrm{P}-41.5 \mathrm{~K}$ & SQM North America & 72 \\
& Boron & $10 \% \mathrm{~B}$ & Sun Coast; Sodus, MI & 10 \\
2016 & Feather meal & $13 \mathrm{~N}-0 \mathrm{P}-0 \mathrm{~K}$ & Mason City By-products & 769 \\
& Potassium sulfate (field only) & $0 \mathrm{~N}-0 \mathrm{P}-41.5 \mathrm{~K}$ & SQM North America & 192 \\
Magnesium sulfate (high tunnel only) & $10 \% \mathrm{Mg}, 13 \% \mathrm{~S}$ & Rite Aide, Camp Hill, PA & 100 \\
Dolomitic lime (field only) & $6 \% \mathrm{Mg}$ & Imerys Carbonates, Roswell, GA & 417 \\
Boron & $10 \% \mathrm{~B}$ & Sun Coast, Sodus, MI & 10 \\
\hline
\end{tabular}

${ }^{\mathrm{z}} 1 \mathrm{lb} /$ acre $=1.1209 \mathrm{~kg} \cdot \mathrm{ha}^{-1}$. 
method (Lee et al., 2005) at the University of Georgia, Agricultural \& Environmental Services Laboratory located in Athens. Midribs were removed from the freeze-dried lettuce samples and the remaining tissue was ground in a food processor. A subsample of $30 \mathrm{mg}$ of lettuce leaf tissue was mixed with $5 \mathrm{~mL} 2 \%$ hydrochloric acid in methanol for $48 \mathrm{~h}$. The liquid extract was separated by centrifugation at $500 g_{\mathrm{n}}$ for $15 \mathrm{~min}$. For each sample, separate $400-\mu \mathrm{L}$ aliquots of extract were added to two test tubes containing $1600 \mu \mathrm{L}$ sodium acetate buffer $(0.4 \mathrm{M}, \mathrm{pH} 4.5)$ and potassium chloride buffer $(0.025 \mathrm{M}, \mathrm{pH} 1.0)$, creating a 1:5 dilution. Two hundred microliters of the mixed sample was pipetted into a 96-well plate. Absorbance was measured at 520 and $720 \mathrm{~nm}$ (SpectraMAX 190 Absorbance Microplate Reader; Molecular Devices, San Jose, CA). Total anythocyanin concentrations were expressed as cyanidin-3glucoside equivalent values (Guisti and Wrolstad, 2001).

Statistics. The main factors of comparison were two production systems (i.e., high tunnel vs. field) and eight mini-lettuce cultivars. Variables were about normally distributed, so the statistical analysis was carried out using untransformed data with a mixed-effects analysis of variance model (SAS version 9.4; SAS Institute, Cary, NC). Tukey's mean separation method with 95\% confidence level was used to determine significant differences between the production systems or cultivars. Each year was analyzed separately to account for different weather patterns. Nonsignificant interactions were dropped from the models.

Continuous response variables evaluated for marketable yields included mean head weight, mean head diameter, mean head length, and the number of leaves per head (romaine types only). Individual head weight was obtained by dividing the number of marketable heads by the total marketable yield per plot. The response variable related to the percentage of the crop that was nonmarketable was analyzed differently because it was not a continuous variable. This variable was analyzed with a logistic regression model to predict a proportion of the total harvested heads that were nonmarketable using production system or cultivar as explanatory variables (SAS version 9.4). Again, each year was analyzed separately.
Statistical analysis was not conducted on microenvironmental measurements including air temperature, RH, DLI, and leaf wetness counts (LWC). Hourly averages for air temperature are presented in Fig. 2, and monthly totals or averages for air temperature, RH, DLI, and LWC are presented in Table 2 so that general comparisons between years at our research site and to other studies can be made.

\section{Results}

Microenvironment. Mean monthly air temperatures ranged from 17 to $23{ }^{\circ} \mathrm{C}$ across the high tunnel and field system both years (Table 2). The 2015 season was slightly warmer than 2016 and experienced less temperature fluctuations (Fig. 2). The greatest temperature differences between the high tunnel and field system were on the coldest evenings when the high tunnel dropdown side curtains were programmed to close at $\approx 10{ }^{\circ} \mathrm{C}$; high tunnel temperatures were 2 to $5{ }^{\circ} \mathrm{C}$ higher than the field during those periods (Fig. 2). In 2016, the lowest recorded temperature was $6^{\circ} \mathrm{C}$ under the high tunnels compared $1{ }^{\circ} \mathrm{C}$ in the field (Fig. 2). Lettuce plants did not show signs of cold damage at any time in either system.

Mean $\mathrm{RH}$ was similar between the high tunnels and field; however, RH was greater in Apr. 2015 compared with Apr. 2016, presumably due to more precipitation (Table 2). Mean LWC demonstrated that the high tunnel leaf tissue was dry more often than leaf tissue in the field during April and May of both years (Table 2). Mean LWC for the field ranged from 4 to $11 \mathrm{~h}$ per day in 2015 and 4 to 7 h per day in 2016 compared with 0 to $<1 \mathrm{~h}$ for the high tunnels both years (Table 4 ). Light quality represented by the DLI indicated that high tunnel and field crops received slightly more visible light in 2016 compared with 2015 , likely due to fewer days with precipitation (i.e., cloud cover) (Table 2). In 2015, the mean DLI was $31 \%$ to $33 \%$ lower under the high tunnels compared with the field and in 2016, the mean DLI was $40 \%$ to $44 \%$ lower under the high tunnels compared with the field (Table 2).
YIELD. Mini-lettuce was harvested an average of 36 to $40 \mathrm{~d}$ after transplanting in 2015 and 2016, respectively, from both systems. The mean lettuce head weight ranged from 101 to $178 \mathrm{~g}$ across the 2 years and systems (Table 3 ). In 2015, the mean lettuce head weight was not statistically different among the two systems, but in 2016, the mean head weight was $43 \%$ greater in the high tunnels compared with the field (Table 3). From 2015 to 2016 , the mean high tunnel lettuce head weight increased by $30 \%$, whereas the mean field lettuce head weight decreased by 27\% (Table 3 ).

The marketability of the minilettuce crop ranged from $86 \%$ to $95 \%$ across the two systems and years (Table 3). In 2015, the high tunnels had a greater amount of culls compared with the field, but in 2016 the rates were not different (Table 3 ). Undersized heads were the major reason for lettuce culls across systems and years and represented $87 \%$ to $100 \%$ of the total nonmarketable harvest. Bolting, tipburn, and insect damage were also observed in small quantities.

Mini-lettuce head diameter, head length, and the number of leaves per head were also compared. The mean lettuce head diameter ranged from 5.4 to $8.1 \mathrm{~cm}$ across the years and both systems. The mean lettuce head diameter grown under high tunnels was $17 \%$ to $28 \%$ wider compared with the field in 2015 and 2016, respectively (Table 3). A system comparison of the mean lettuce head length ranged from 8.7 to $12.2 \mathrm{~cm}$ across the years (Table $3)$. In 2015 , there was no significant difference in lettuce head length across the systems but in 2016, the lettuce grown under the high tunnels was 2.2 $\mathrm{cm}$ longer than field-grown (Table 3). A system comparison found that the mean leaf number ranged from 16 to 19 individual leaves per head (Table $3)$. In 2015 , there was no significant difference in the mean leaf number, but in 2016, the lettuce grown under the high tunnels had an average of two or more leaves per head than fieldgrown (Table 3 ).

A comparison of mean marketable mini-lettuce head weight by cultivar ranged from 79 to $190 \mathrm{~g}$ depending on the year (Table 4). 'Bambi' had consistently high yields in both systems across both years 
(Table 4). Percent marketability was not different among lettuce cultivars in 2015 or 2016 and averaged $94 \%$ and $91 \%$, respectively (Table 4 ).

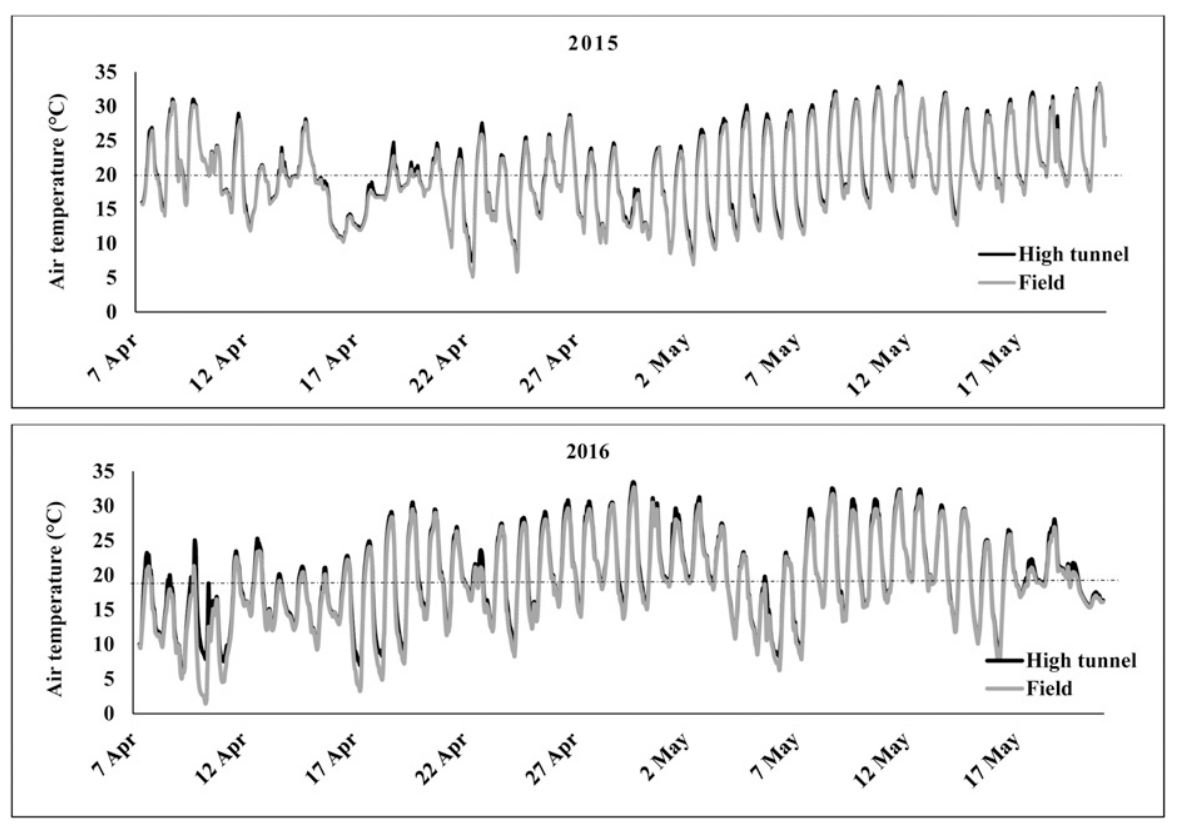

Fig. 2. Mean hourly temperatures from 7 Apr. to 20 May under high tunnels and the field during 2015 and 2016 in Watkinsville, GA. The dotted line at $20{ }^{\circ} \mathrm{C}$ represents the set point when automated high tunnel side curtains vented; $\left(1.8 \times{ }^{\circ} \mathrm{C}\right)+32={ }^{\circ} \mathrm{F}$.
Breen, Spretnak, and Rhazes in 2016 (Table 4). The first year, 'Breen' romaine had significantly longer heads than all other cultivars, and Baby Green Oakleaf butterhead was shorter than four other cultivars (Table 4). The trend was similar the second year with 'Breen' measuring longer than four of the eight cultivars (Table 4). Both years, 'Breen' had more individual leaves compared with 'Bambi' and 'Rhazes' (Table 4). In 2015 , there were no production system by cultivar interactions for crop yield (Fig. 4). In 2016, the mean marketable head weight for 'Baby Green Oakleaf' was $3 \times$ greater and 'Spretnak' was $2 \times$ greater when grown under high tunnels compared with the field (Fig. 3).

Anthocyanins. In 2015, visual assessments to characterize external leaf tissue color differences were detectable by the naked eye. It was estimated that field-grown, 'Australe', 'Breen', 'Maraine', and 'Rhazes' had $30 \%$ to $60 \%$ greater red pigmentation compared with high tunnel-grown lettuce (Fig. 4). In 2016 , to further quantify the differences, the anthocyanin concentrations of the

Table 2. Mean monthly air temperature, relative humidity (RH), leaf wetness count (LWC), and daily light integral (DLI) for mini-lettuce cultivar trial under organically managed high tunnels or field, across two spring seasons in Watkinsville, GA.

\begin{tabular}{|c|c|c|c|c|c|c|c|c|}
\hline \multirow[b]{3}{*}{ Yr } & \multirow[b]{3}{*}{ Month $^{\mathrm{z}}$} & \multirow[b]{3}{*}{ System } & \multicolumn{6}{|c|}{ Measurements } \\
\hline & & & \multicolumn{3}{|c|}{ Air temp $\left({ }^{\circ} \mathrm{C}\right)^{\mathrm{y}}$} & \multirow{2}{*}{$\frac{\mathrm{RH}(\%)}{\text { Mean }}$} & \multirow{2}{*}{$\frac{\text { LWC }\left(\mathbf{h} \cdot \mathbf{d}^{-1}\right)}{\text { Mean }}$} & \multirow{2}{*}{$\frac{\text { DLI }\left(\mathrm{mol} \cdot \mathrm{m}^{-2} \cdot \mathrm{d}^{-1}\right)}{\text { Mean }}$} \\
\hline & & & $\overline{\text { Min }}$ & Mean & $\overline{M a x}$ & & & \\
\hline & & Field & 5 & 18 & 28 & 81 & 11 & 32 \\
\hline & May & High tunnel & 8 & 23 & 34 & 69 & 0 & 35 \\
\hline & & Field & 7 & 22 & 33 & 70 & 7 & 52 \\
\hline & May & High tunnel & 8 & 21 & 33 & 68 & $<1$ & 25 \\
\hline & & Field & 6 & 20 & 32 & 69 & 4 & 45 \\
\hline
\end{tabular}

${ }^{\mathrm{z}} 10$ to 30 Apr. 2015,1 to 19 May 2015,7 to 30 Apr. 2016, and 1 to 20 May 2016.

${ }^{\mathrm{y}} \mathrm{Min}=\operatorname{minimum}, \operatorname{Max}=\operatorname{maximum} ;\left(1.8 \times{ }^{\circ} \mathrm{C}\right)+32={ }^{\circ} \mathrm{F}$.

Table 3. Mean mini-lettuce weight, percent marketability, head diameter, head length, and leaf number by organically managed high tunnels or field, across two spring seasons in Watkinsville, GA.

\begin{tabular}{|c|c|c|c|c|c|c|}
\hline \multirow[b]{2}{*}{$\underline{Y r^{z}}$} & & \multicolumn{5}{|c|}{ Measurements $^{\mathrm{y}}$} \\
\hline & & Head wt (g) & Marketability (\%) & Head diam $(\mathrm{cm})$ & Head length $(\mathrm{cm})$ & Leaves (no.) \\
\hline \multirow[t]{2}{*}{2015} & High tunnel & 147 & $86 a^{x}$ & $8.1 \mathrm{a}$ & 11.9 & 16 \\
\hline & $P$ value & NS & $\leq 0.05$ & $\leq 0.001$ & NS & NS \\
\hline \multirow[t]{2}{*}{2016} & High tunnel & $178 \mathrm{a}$ & 92 & $6.9 \mathrm{a}$ & $10.9 \mathrm{a}$ & $19 b$ \\
\hline & Field & $101 \mathrm{~b}$ & 89 & $5.4 \mathrm{~b}$ & $8.7 \mathrm{~b}$ & $17 \mathrm{a}$ \\
\hline
\end{tabular}

${ }^{\mathrm{z}}$ Each growing season was analyzed separately.

${ }^{\mathrm{y}} 1 \mathrm{~g}=0.0353 \mathrm{oz} ; \mathrm{l} \mathrm{cm}=0.3937$ inch

${ }^{x}$ Values followed by different letters are significantly different within a column according to Tukey's mean separation test $(P \leq 0.05)$.

NS $=$ not significant. 
Table 4. Mean mini-lettuce weight, percent marketability, head diameter, head length, and leaf number by cultivar under organically managed production systems, across two spring seasons in Watkinsville, GA.

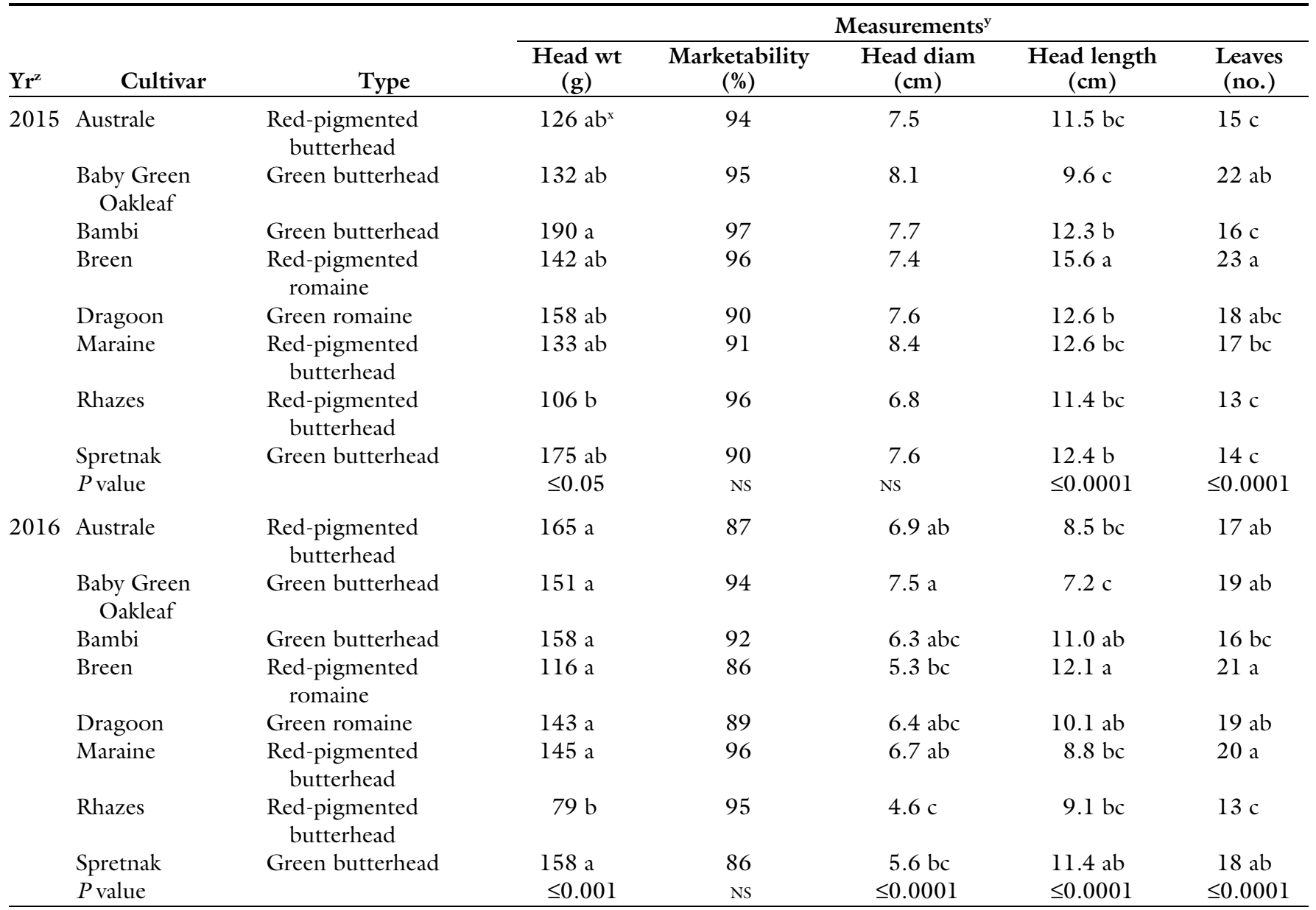

${ }^{\mathrm{z}}$ Each growing season was analyzed separately.

${ }^{\mathrm{y}} 1 \mathrm{~g}=0.0353 \mathrm{oz}, 1 \mathrm{~cm}=0.3937$ inch.

${ }^{\mathrm{x}}$ Values followed by different letters are significantly different within a column according to Tukey's mean separation test $(P \leq 0.05)$.

NS $=$ not significant.

external leaves from the red-pigmented lettuces were analyzed. The average anthocyanin concentration for fieldgrown lettuce was $153 \%$ greater than the high tunnel-grown (Table 5). 'Rhazes' had the greatest anthocyanin concentrations followed by 'Breen' and 'Maraine', and then 'Australe' (Table 5). Field-grown, red-pigmented lettuce had $26 \%$ to $194 \%$ greater anthocyanin levels compared with high tunnel-grown but only 'Rhazes' demonstrated a significant production system by cultivar interaction (Table 6).

\section{Discussion}

The high tunnel and field environments had similar mean air temperatures during our two spring seasons, although 2015 had a warmer beginning of the season compared with 2016. The high tunnels provided a 2 to $5{ }^{\circ} \mathrm{C}$ heat gain on the coldest days. Relative humidity was similar in the high tunnels and field, but LWCs were much greater for the field. There were more precipitation events in 2015 compared with 2016 , which is reflected in longer periods of LW in the field during the first spring season. Generally, decreased LW is considered a valuable disease prevention tool that well-ventilated high tunnels can provide, although our mini-lettuce crops were not heavily affected by disease in either 2015 or 2016 (Frey et al., 2020; Huber and Gillespie, 1992).

The DLI under our inflated double-layer high tunnel polyethylene film roofs was $\approx 30 \%$ lower and then $40 \%$ lower than the field when the film was 2 and 3 years old, respectively. A high tunnel study in Washington found a $27 \%$ to $36 \%$ reduction in average light intensity under high tunnels compared with the field with a single layer of ultraviolet-treated greenhouse plastic although the age of the film was not presented (Borrelli et al., 2013). The decrease in DLI over time indicates that the high tunnel polyethylene film was degrading resulting in a visible light decrease under the high tunnels. However, even with the decreased DLI under the high tunnels, the lowest DLI levels were $\geq 22 \mathrm{~mol} \cdot \mathrm{m}^{-2} \cdot \mathrm{d}^{-1}$, which was still consistently above the optimal light requirements for lettuce [i.e., 15 to $20 \mathrm{~mol} \cdot \mathrm{m}^{-2} \cdot \mathrm{d}^{-1}$ (Runkle, 2011)]. The DLI data suggest that our double-layered polyethylene film roof would need replacing in the near future to ensure sufficient light penetration for crops with $\geq 20 \mathrm{~mol} \cdot \mathrm{m}^{-2} \cdot \mathrm{d}^{-1}$ light requirements [i.e., tomato, cucumber, etc. (Runkle, 2011)]. Alternate ways to extend the lifespan of the film might include growing crops with lower light requirements, such as lettuce and/or growing crops where low 


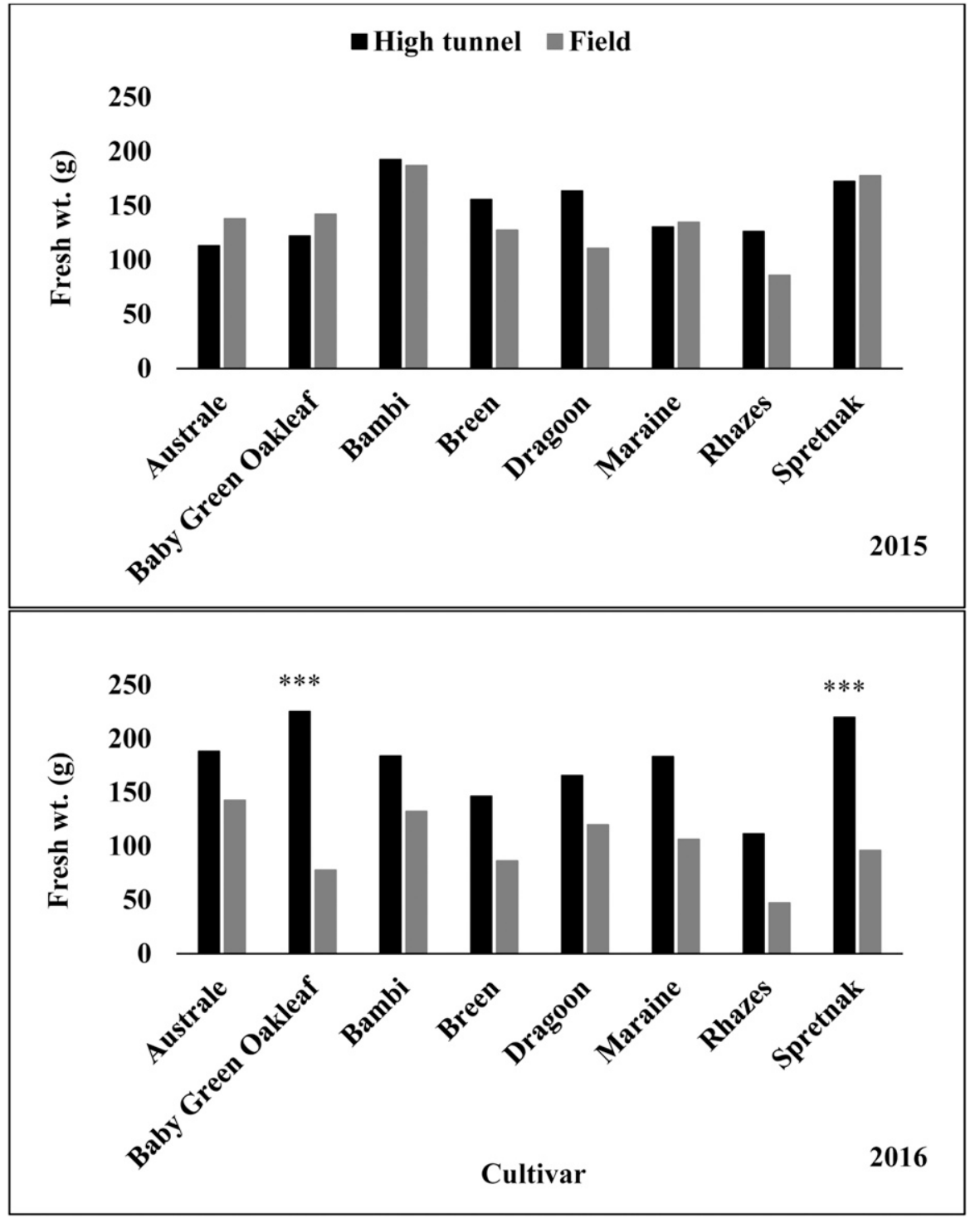

Fig. 3. The interaction between production system (i.e., high tunnel or field) and mini-lettuce cultivar for mean marketable yield in 2015 (top) and 2016 (bottom) in Watkinsville, GA. Interactions that were significantly different according to Tukey's mean separation at $P \leq 0.001$ are denoted by ${ }^{* * *} ; 1 \mathrm{~g}=0.0353 \mathrm{oz}$.

light conditions encourage plant elongation or other desired qualities.

In 2015 , the mini-lettuce yield (i.e., mean marketable head weight) was similar between the high tunnels and the field, but in 2016, the yield was greater under the high tunnels. Our results are similar to other studies that have found high tunnels can boost yields but that biotic or abiotic variables can affect crop yields in any given year (Jayalath et al., 2017; O'Connell and Tate, 2017; O'Connell et al., 2012; Rho et al., 2020; Wallace et al., 2012). It is unclear why the high tunnel system had yield increases in 2016, while overall the field system had yield decreases compared with 2015. Additional abiotic factors that were not investigated and may have had an influence on crop yield in either system include wind stress, soil moisture, nutrient leaching, and additional aspects of light quality and quantity.

Most mini-lettuce cultivars were similar in terms of marketable weight and head diameter, indicating that they could be interchanged or mixed and matched if desired; most also achieved similar levels of quality in terms of marketability. In general, combining three to four mini-lettuce heads would be the equivalent of a full-size lettuce head by weight and comparable to the contents of a mini-lettuce four-pack currently found in supermarket chains (e.g., $\approx 452$ g) (Jayalath et al., 2017; Zhao and Carey, 2009). 'Rhazes' was an exception because it demonstrated lower head weights than most other cultivars, although our weight values were similar to those reported elsewhere (Takahashi and Cardoso, 2014).

In 2016, 'Baby Green Oakleaf' and 'Spretnak' yielded greater marketable yields when grown under the high tunnels compared with the field. Although not conclusive, this indicates that 'Baby Green Oakleaf' and 'Spretnak' benefitted from the high tunnel system. Other studies have identified vegetable, fruit or flower cultivars that appeared to achieve enhanced growth under high tunnels (Jayalath, 2016; Ortiz et al., 2012; Rowley et al., 2011; Warren et al., 2015). Farmers and plant breeders may be able to use this information to select or further develop cultivars specifically for high tunnel production in their region.

Red-pigmented mini-lettuce grown under the high tunnels had $26 \%$ to $194 \%$ lower anthocyanin concentrations compared with the field. The cultivar Rhazes had the greatest anthocyanin concentrations evaluated. 'Rhazes' anthocyanin concentrations were significantly lower when grown under high tunnels compared with the field, while the other three redpigmented cultivars followed a similar trend. However, 'Rhazes' also had the lowest yields of the redpigmented cultivars. The results suggest an inverse relationship may be present between anthocyanin content and yield for 'Rhazes', but it was not statistically significant in our study. Although we examined DLI and not ultraviolet light, our results generally concur with studies that measured the effect of ultraviolet light (Garcia-Macias et al., 2007; Ordidge et al., 2010; Tsormpatsidis et al., 2008). It appears that the visible light spectrum also has a measurable impact on anthocyanin accumulation. It is difficult to provide an estimate of the total anthocyanin content because our results reflect only the outer leaves, whereas consumers generally eat the entire head of lettuce. A future study that estimates the average anthocyanin content of all edible portions of redpigmented mini-lettuce heads would add to the limited information about 


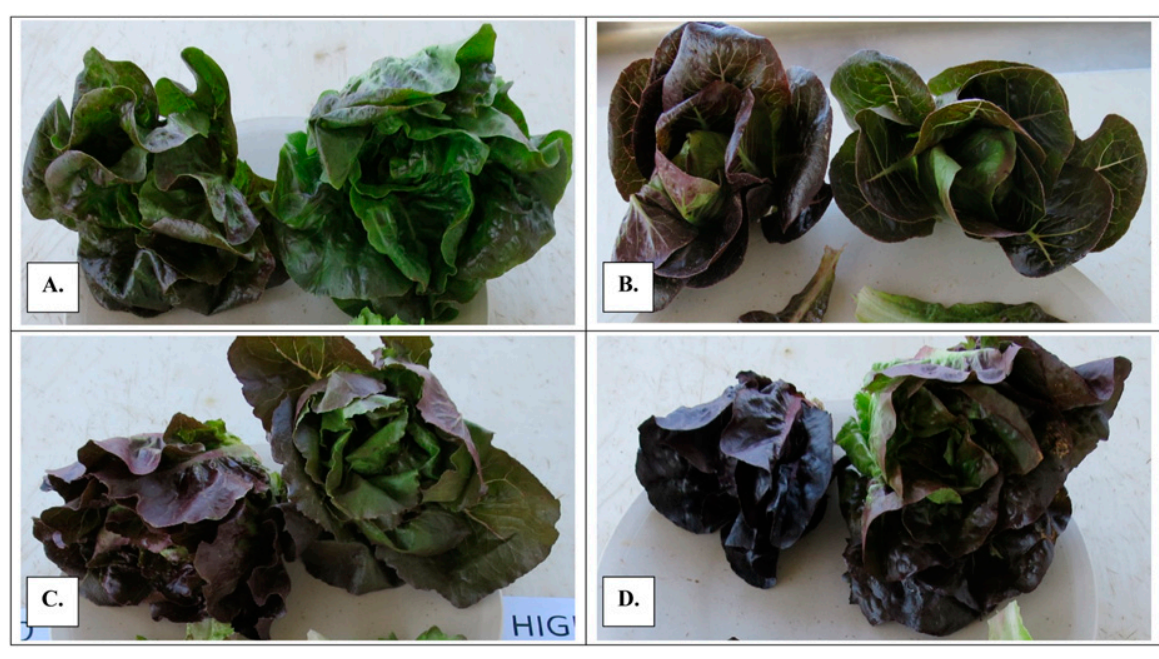

Fig. 4. Photos of harvested mini-lettuce heads with red pigmentation from the Spring 2016 season in Watkinsville, GA. Field-grown mini-lettuce is shown on the left side of each quadrant, while high tunnel-grown lettuce is shown on the right side of each quadrant. The mini-lettuce cultivars are presented in the following order: (A) Australe, (B) Breen, (C) Maraine, and (D) Rhazes.

Table 5. The effects of production system and cultivar on anthocyanin (cyanidin-3glucoside) concentrations of red-pigmented mini-lettuce at Watkinsville, GA in 2016.

\begin{tabular}{lc}
\hline & Mean anthocyanin concn $(\mathrm{g} / \mathbf{1 0 0} \mathrm{g})^{\mathrm{z}}$ \\
\hline System & \\
High tunnel & $0.60 \mathrm{~b}^{\mathrm{y}}$ \\
Field & $1.52 \mathrm{a}$ \\
$P$ value & $<0.0001$ \\
Cultivar & \\
Australe & $0.31 \mathrm{c}^{\mathrm{y}}$ \\
Breen & $1.12 \mathrm{~b}$ \\
Maraine & $0.86 \mathrm{~b}$ \\
Rhazes & $1.95 \mathrm{a}$ \\
$P$ value & $<0.0001$ \\
\hline
\end{tabular}

${ }^{\mathrm{z}}$ Evaluation from a pooled sample of 10 external leaves from two marketable heads; $1 \mathrm{~g} / 100 \mathrm{~g}=1 \%$.

${ }^{y}$ Values followed by the same letter are not significantly different within a column according to Tukey's mean separation test $(P \leq 0.05)$.

${ }^{\mathrm{x}}$ Includes cultivars with red pigmentation on external leaf tissue.

Table 6. The interaction between production system and cultivar on anthocyanin (cyanidin-3-glucoside) concentrations of red-pigmented mini-lettuce at Watkinsville, GA in 2016.

\begin{tabular}{|c|c|c|c|}
\hline & \multicolumn{2}{|c|}{$\begin{array}{l}\text { Mean anthocyanin } \\
\text { concn }(\mathrm{g} / 100 \mathrm{~g})^{\mathrm{z}}\end{array}$} & \multirow[b]{2}{*}{ Difference (\%) } \\
\hline & High tunnel & $\overline{\text { Field }}$ & \\
\hline \multicolumn{4}{|l|}{ Cultivar ${ }^{\mathrm{y}}$} \\
\hline Australe & $0.27 \mathrm{a}^{\mathrm{x}}$ & $0.34 \mathrm{a}$ & 26 \\
\hline Breen & $0.67 \mathrm{a}$ & $1.56 \mathrm{a}$ & 133 \\
\hline Maraine & $0.47 \mathrm{a}$ & $1.25 \mathrm{a}$ & 166 \\
\hline Rhazes & $0.99 \mathrm{~b}$ & $2.91 \mathrm{a}$ & 194 \\
\hline \multicolumn{4}{|c|}{ Cultivar $\times$ anthocyanin concentration } \\
\hline$P$ value & \multicolumn{2}{|c|}{$<0.005$} & \\
\hline
\end{tabular}

their potential nutritional contribution. In addition, studies that examine the feasibility of supplemental light treatments under high tunnels or if lower ultraviolet-resistant polyethylene film for high tunnel roofs may help growers increase anthocyanin gains while maintaining the benefits of producing lettuce under high tunnels.

Mini-lettuce was harvested an average of 36 to $40 \mathrm{~d}$ after transplanting across the two seasons. This is $\approx 7$ to $20 \mathrm{~d}$ earlier than full-size lettuce heads of the same type (i.e., butterhead and romaine) indicating a quicker crop turn-over that could result in greater profits (Jayalath et al., 2017; Johnny's Selected Seeds, 2013; Kaiser and Ernst, 2017; Wallace et al., 2012). Although our in-row spacing (i.e., 6 inches) appeared appropriate to allow for good air circulation among plants, the between-row spacing (i.e., 12 inches) appeared too generous. Further evaluations of plant space density for mini-lettuces would help maximize potential crop yields. In addition, drip tape with more closely spaced emitters (i.e., every 6 inches compared with every 8 inches) would have delivered water more evenly to each plant, resulting in more efficient and shorter irrigation intervals.

Overall, mini-lettuce appeared to be a viable, quick crop that high tunnel farmers could produce to help fill the demand for organic salad greens. Many of the mini-lettuce cultivars evaluated performed well under high tunnels and the field. High tunnels appeared to boost the yield of two cultivars, Baby Green Oakleaf and Spretnak, at least in 1 year. Yields of red-pigmented mini-lettuces were comparable to green cultivars, with the exception of the lower-yielding 'Rhazes'. Continuing to refine practices and identify/develop mini-lettuce cultivars for this region would help optimize high tunnel productivity and profitability.

\section{Literature cited}

Borrelli, K., R.T. Koenig, B.M. Jaeckel, and C.A. Miles. 2013. Yield of leafy greens in high tunnel winter production in the northwest United States. HortScience 48(2):183-188, doi: 10.21273/ HORTSCI.48.2.183.

Frey, C.J., X. Zhao, J.K. Brecht, D.M. Huff, and Z.E. Black. 2020. High tunnel and grafting effects on organic tomato plant disease severity and root-knot nematode infestation in a subtropical climate with sandy soils. HortScience 30(4):492-503, doi: 10.21273/HORTSCI14166-19.

Garcia-Macias, P., M. Ordidge, E. Vysini, S. Waroonphan, N.H. Battey, M.H. Gordon, P. Hadley, P. John, J.A. Love- 
grove, and A. Wagstaffe. 2007. Changes in the flavonoid and phenolic acid contents and antioxidant activity of red leaf lettuce (Lollo Rosso) due to cultivation under plastic films varying in ultraviolet transparency. J. Agr. Food Chem. 55(25):10168-10172, <https://pubs. acs.org/doi/10.1021/jf071570m>.

Guisti, M.M. and R.E. Wrolstad. 2001. Characterization and measurement of anthocyanins by UV-visible spectroscopy. Current Protoc. Food Anal. Chem 00(1):F1.2.1-F1.2.13, doi: 10.1002/ 0471142913.faf0102s00.

Huber, L. and T.J. Gillespie. 1992. Modeling leaf wetness in relation to plant disease epidemiology. Annu. Rev. Phytopathol. 30:553-577, <https://www. annualreviews.org/doi/10.1146/ annurev.py.30.090192.003005>.

Jayalath T.C. 2016. The evaluation of high tunnel lettuce production in Georgia. Univ. of GA. MS Thesis. <https:// getd.libs.uga.edu/pdfs / jayalath_ theekshana_c_201612_ms.pdf $>$.

Jayalath, T.C., G.E. Boyhan, E.L. Little, R.I. Tate, and S. O'Connell. 2017. High tunnel and field system comparison for spring organic lettuce production in Georgia. HortScience 52(11):1518-1524, doi: 10.21273/HORTSCI12284-17.

Johnny's Selected Seeds. 2013. Growing mini versus full-size head lettuce. 17 Nov. 2018. <http://www.johnnyseeds.com/ growers-library/vegetables/mini-versus-fullhead-lettuce.html?q= mini\%20lettuce $>$.

Kaiser, C. and M. Ernst. 2017. Baby vegetables. Univ. Kentucky, Ctr. Crop Diversification CCD-CP-86. 17 Nov. 2018. <http://www.uky.edu/ccd/sites/www. uky.edu.ccd/files/babyveggies.pdf>.

Khoo, H.E., A. Azlan, S.T. Tang, and S.M. Lim. 2017. Anthocyanidins and anthocyanins: Colored pigments as food, pharmaceutical ingredients, and the potential health benefits. Food Nutr. Res. 61:1361779, doi: 10.1080/16546628.2017.1361779.

Krizek, D.T. 2004. Influence of PAR and UV$\mathrm{A}$ in determining plant sensitivity and photomorphogenic responses to UV-B radiation. Photochem. Photobiol. 79(4):307-315, <https://onlinelibrary.wiley.com/doi/abs/ 10.1111/j.1751-1097.2004.tb00013.x>.

Kuepper, G., J. Bachmann, and R. Thomas. 2002. Speciality lettuce and greens: Organic production. 5 Sept. 2020. <https://attra. ncat.org/product/specialty-lettuce-greensorganic-production $/>$.

Lee, J., R.W. Durst, and R.E. Wrolstad. 2005. Determination of total monomeric anthocyanin pigment content of fruit juices, beverages, natural colorants, and wines by the $\mathrm{pH}$ differential method: Collaborative study. J. AOAC Intl. 88(5):1269-1278,

Maynard, D.N. 2006. Production of miniature vegetables in Florida. Univ. Florida, Inst. Food Agr. Sci. HS36. 1 Nov. 2020. <https://ufdcimages.uflib.ufl.edu/IR/ 00/00/27/37/00001/HS32700.pdf>.

McGhies, T.K. and M.C. Walton. 2007. The bioavailability and absorption of anthocyanins: Towards a better understanding. Mol. Nutr. Food Res. 51(6):702-713. <https:// onlinelibrary.wiley.com/doi/abs/10.1002/ mnfr.200700092>.

Minich, D.M. 2019. A review of the science of colorful, plant-based food and practical strategies for "eating the rainbow". J. Nutr. Metab. 2019:2125070, doi: $10.1155 / 2019 / 2125070$.

O'Connell, S., C. Rivard, M.M. Peet, C. Harlow, and F. Louws. 2012. High tunnel and field production of organic heirloom tomatoes: Yield, fruit quality, disease and microclimate. HortScience 47(9):1283-1290, doi: 10.21273/HORTSCI.47.9.1283.

O'Connell, S. and R. Tate. 2017. Winter broccoli and cauliflower under organic high tunnels in a humid, subtropical climate. HortScience 52(11):1511-1517, doi: 10.21273/HORTSCI12291-17.

Ordidge, M.A., P. García-Macías, N.H. Battey, M.H. Gordon, P. Hadley, P. John, J.A. Lovegrove, E. Vysini, and A. Wagstaffe. 2010. Phenolic contents of lettuce, strawberry, raspberry, and blueberry crops cultivated under plastic films varying in ultraviolet transparency. Food Chem. 119(3):1224-1227, doi: 10.1016/j.foodchem.2009.08.039.

Ortiz, M.A., K. Hyrczyk, and R.G. Lopez. 2012. Comparison of high tunnel and field production of specialty cut flowers in the midwest. HortScience 47(9):1265-1269, doi: 10.21273/HORTSCI.47.9.1265.

Rho, H., P. Colaizzi, J. Gray, L. Paetzold, Q. Xue, B. Patil, and C. Rush. 2020. Yields, fruit quality, and water use in a jalapeno pepper and tomatoes under open field and hightunnel production systems in the Texas high plains. HortScience 55(10):1632-1641, doi: 10.21273/HORTSCI15143-20.

Rogers, M.A. and A.L. Wszelaki. 2012 Influence of high tunnel production and planting date on yield, growth, and early blight development on organically grown heirloom and hybrid tomato. HortTechnology 22(4):452-462, doi: 10.21273/ HORTTECH.22.4.452.

Rowley, D., B.L. Black, D. Drost, and D. Feuz. 2011. Late-season strawberry production using day-neutral cultivars in high-elevation high tunnels. HortScience 46(11):1480-1485, doi: 10.21273/ HORTSCI.46.11.1480.
Runkle, E. 2011. Lighting greenhouse vegetables. 22 Aug. 2016. <http://www. flor.hrt.msu.edu/assets / Uploads / Lightingvegetables.pdf $>$.

Saltveit, M.E. 2003. Freshcut vegetables, p. 671-712. In: J.A. Bartz and J.K. Brecht (eds.). Postharvest physiology and pathology of vegetables. Marcel Dekker, New York, NY.

Schaffiner, D.J. 2002. United States produce markets in transition-Today and tomorrow. J. Food Distrib. Res. 33(2):61-66, 1 Nov. 2020. <http://citeseerx.ist.psu.edu/viewdoc/ download;jsessionid $=$ D6D3548702531 D544AEF9582A356EBCl ?doi=10.1.1. $565.109 \&$ rep $=$ repl \&type $=$ pdf $>$.

Schifferstein, H.N.J., T. Wehrle, and C.-C. Carbon. 2019. Consumer expectations for vegetables with typical and atypical colors: The case of carrots. Food Qual. Prefer. 72:98108, doi: 10.1016/j.foodqual.2018.10.002.

Stafford, H.A. 1994. Anthocyanins and betalains: Evolution of the mutually exclusive pathways. Plant Sci. 101(2):91-98, doi: 10.1016/0168-9452(94)90244-5.

Steyn, W.J., S.J.E. Wand, D.M. Holcroft, and G. Jacobs. 2002. Anthocyanins in vegetative tissues: A proposed unified function in photoprotection. New Phytol. $155(3): 349-361$, https://nph. onlinelibrary.wiley.com/doi/abs/10. 1046/j.1469-8137.2002.00482.x.

Takahashi, K. and A. Cardoso. 2014. Plant density in production of mini lettuce cultivars in organic system management. Hort. Bras. 32(3):342-347, doi: 10.1590/ S0102-05362014000300017.

Tsormpatsidis, E., R.G.C. Henbest, F.J. Davis, N.H. Battey, P. Hadley, and A. Wagstaffe. 2008. UV irradiance as a major influence on growth, development and secondary products of commercial importance in Lollo Rosso lettuce 'Revolution' grown under polyethylene films. Environ. Expt. Bot 63(1-3):232-239, doi: 10.1016/j.envexpbot.2007.12.002.

U.S. Department of Agriculture. 1968. Soil survey of Clarke and Oconee counties. 12 Jan. 2014. <http://www.nrcs.usda.gov/ Internet/FSE_MANUSCRIPTS / georgia/clarke_oconeeGA1968/CO.pdf>.

U.S. Department of Agriculture. 2012. Plant hardiness zone map. 24 Aug. 2015. $<$ http://planthardiness.ars.usda.gov/ $\mathrm{PHZMWeb} />$.

U.S. Department of Agriculture. 2015. Conservation practice standard-High tunnel system - Code $325-\left(\mathrm{ft}^{2}\right) .9$ Nov. 2020. <https://www.nrcs.usda.gov/ wps / PA_NRCSConsumption / download ? cid $=$ nrcseprd $656807 \&$ $\mathrm{ext}=\mathrm{pdf}>$. 
U.S. Department of Agriculture. 2017a. Lettuce. 8 Sept. 2018. <https://www. agmrc.org/commodities-products / vegetables/lettuce $>$.

U.S. Department of Agriculture. 2017b. 2016 certified organic highlights, \#20176. 8 Sept. 2018. <https://www.nass. usda.gov/Publications/Highlights/ 2017/2016_Certified_Organic_Survey_ Highlights.pdf $>$.

U.S. Department of Agriculture. 2019. 2017 Census of agriculture state level data Georgia. 7 Nov. 2020. <https://www. nass.usda.gov/Publications/AgCensus/ 2017/Full_Report/Volume_1,_Chapter_ 1_State_Level/Georgia/st13_1_0036_ 0036.pdf>.

U.S. Department of Agriculture. 2020. 2019 Organic survey. Natl. Agr. Stat. Serv. AC-17-SS-4. 7 Nov. 2020. <https://www. nass.usda.gov/Publications/AgCensus/ 2017/Online_Resources/Organics/ ORGANICS.pdf $>$.

U.S. Department of Health and Human Services and U.S. Department of Agriculture. 2015. Dietary guidelines for Americans, 2015-2020. 8th ed. 1 Nov.
2020. <https://www.dietaryguidelines. gov/sites/default/files/2019-05/20152020_Dietary_Guidelines.pdf>.

U.S. Government Publishing Office. 1990. 7 U.S. Code $\$ 6507$ - State organic certification program. 22 Aug. 2015. <http://www.gpo.gov/fdsys/granule/ USCODE- 2011 - title $7 /$ USCODE2011-title7-chap94-sec6507>.

Wallace, R.W., A.L. Wszelaki, C.A. Miles, J.S. Cowan, J. Martin, J. Roozen, B. Gunderson, and D.A. Inglis. 2012. Lettuce yield and quality when grown in high tunnel and open-field production systems under three diverse climates. HortTechnology 22(5):659-668, doi: 10.21273/ HORTTECH.22.5.659.

Wallace, T.C. and M.M. Guisti. 2015. Anthocyanins. Adv. Nutr. 6(5):620-622, doi: 10.3945/an.115.009233.

Warren, N., R. Sideman, and R. Smith. 2015. Performance of high tunnel tomato cultivars in northern New England. HortTechnology 25(1):139-146, doi: 10.21273/HORTTECH.25.1.139.
Waycott, W. and E.J. Ryder. 1994. 'Ice Cube', 'Blush', and 'Mini-Green': Miniature crisphead lettuce cultivars. HortScience 29(4):333-334, doi: 10.21273/ HORTSCI.29.4.333.

Wu, X., G.R. Beecher, J.M. Holden, D.B. Haytowitz, S.E. Gebhardt, and R.L. Prior. 2006. Concentrations of anthocyanins in common foods in the United States and estimation of normal consumption. J. Agr. Food Chem. 54(11):20694075. <https://pubs.acs.org/doi/10. 1021/jf060300l>

Zhao, X. and E.E. Carey. 2009. Summer production of lettuce and microclimate in high tunnel and open field plots in Kansas. HortTechnology 19(1):113-119, doi: 10.21273/HORTSCI.19.1.113.

Zhao, X., J.K. Brecht, N.S. Dufault, M. Swisher, K. Sattanno, C. Legaspi, Z. Gao, B.R. Thaxton, A. Bolques, R.L. Meagher, Jr., S. O'Connell, M. Mesh, and A. Rolls. 2017. High tunnel planning projectFollow-up questionnaire report. 10 Nov. 2018. <https://floridafoodandag.com/ new-home/high-tunnel-planningproject>. 